\title{
Very low calorie diet without aspartame in obese subjects: improved metabolic control after 4 weeks treatment
}

\author{
Erik Norén ${ }^{{ }^{*}}$ and Henrik Forssell ${ }^{1,2}$
}

\begin{abstract}
Background: Very low calorie diet (VLCD) is routinely used in programs for treatment of obesity and before bariatric surgery in order to reduce risk of postoperative complications. Aspartame, an artificial sweetener, is commonly used in VLCD and is well approved as a food additive without any adverse effects. The development of a new fructose containing VLCD formula without aspartame raises questions as to effects on glucose and lipid control.

Methods: As part of an ongoing study of a novel bariatric surgery procedure, twenty-five obese subjects with mean body mass index (BMI) $39.8 \mathrm{~kg} / \mathrm{m}^{2}$ and mean age of 48.8 years enrolled in a single center observational study. Seven subjects presented with type 2 diabetes mellitus. The subjects underwent four weeks dietary treatment with VLCD Slanka (Slanka ${ }^{\oplus}$ ). Blood samples including fasting plasma glucose, $\mathrm{HbA1c}$, cholesterol and triglycerides were performed at start and after four weeks of diet. Blood pressure and weight were noted.

Results: All subjects completed the diet without any adverse events. Mean weight reduction was $8.2 \mathrm{~kg}$ with 95\% confidence interval $7.1-9.2 \mathrm{~kg}(\mathrm{p}=0.001)$. Excess weight (i.e. proportion of weight exceeding BMI 25 ) loss decreased by median 19.5\% (inter quartile range (IQR) 16,8-24,2). Median fasting plasma glucose was at inclusion $5,6 \mathrm{mmol} / \mathrm{I}(\mathrm{QQR} 5,3-6,8)$ and after diet $4.8 \mathrm{mmol} / \mathrm{I}(\mathrm{QQR} 4,6-5,2)(\mathrm{p}=0.001)$. Median HbA1c changed from 39 $\mathrm{mmol} / \mathrm{mol}(\mathrm{QQR} 37-44)$ to $37 \mathrm{mmol} / \mathrm{mol}(\mathrm{IQR} 35-43)(p=0.001)$. There was also significant reduction in cholesterol and triglyceride levels as well as in systolic blood pressure. Changes in other monitored blood chemistry values were without clinical importance.

Conclusion: Four weeks treatment with fructose containing VLCD of obese subjects preparing for bariatric surgery gave a substantial weight reduction without any significant negative metabolic effects.
\end{abstract}

Keywords: Obesity, VLCD, Fructose, Aspartame, Artificial sweetener, Weight reduction

\section{Background}

Adult obesity is defined by WHO as body mass index (BMI) greater than $30 \mathrm{~kg} / \mathrm{m}^{2}$. Prevalence of obesity has been increasing worldwide over the last few decades. Obesity prevalence in the United States was $35.5 \%$ among men and 35.8\% among women in 2009-2010, with no significant change compared to 2003-2008 [1]. In young and middle aged men and women all-cause mortality risk appear to be directly related to increase in BMI [2]. Bariatric surgery for severe obesity is associated

\footnotetext{
* Correspondence: erik.noren@ltblekinge.se

'Department of General Surgery, Blekinge County Hospital, Lasarettsvägen,

37185 Karlskrona, Sweden

Full list of author information is available at the end of the article
}

with long-term weight loss and decreased overall mortality [3], in both sexes [4].

Very low calorie diet (VLCD) contains less than 800 kcal per day. VLCD are routinely being used prior to bariatric surgery. Such practice reduces liver volume [5], reduces postoperative complication rates and reduces the perceived technical difficulty of the procedure [6].

Aspartame, an artificial sweetener, is commonly used in VLCD and is well approved as a food additive without any adverse effects [7]. This has also been proven for heterozygotes for phenylketonuria (PKU) [8]. The development of a new VLCD formula (Slanka ${ }^{\circ}$ ) with fructose instead of aspartame raises questions as to effects on glucose and lipid control. 
The total amount of carbohydrates in the Slanka formula is $37 \mathrm{~g}$ per $100 \mathrm{~g}$. The daily amount of formula consumed during diet is approximately $180 \mathrm{~g}$ of which fructose is approximately $20 \mathrm{~g}$. According to a review of health implications of fructose consumption [9], moderate fructose consumption of less than $50 \mathrm{~g} /$ day probably does not have any deleterious effect on lipid and glucose control. It is also known that diet rich in carbohydrates may have an increased risk of metabolic side effects [10].

The aim of this observational study is to investigate the effects of fructose containing VLCD in obese subjects, prior to bariatric intervention, on selected metabolic variables.

\section{Methods}

As part of our ongoing single-center prospective study of a novel bariatric surgery procedure (Forssell H, Norén E, Six Month Results with Aspire Assist ${ }^{\circ}$ - a Novel Endoscopic Weight Loss Therapy, submitted manuscript), twenty-five obese subjects consecutive enrolled after consent from the Regional Ethical Review Board in Lund, Sweden.

Baseline demographics are presented in Table 1. In summary there were 23 women and 2 men with mean BMI $39.8 \mathrm{~kg} / \mathrm{m}^{2}$ and mean age 48.8 years. Seven subjects presented with type 2 diabetes mellitus (T2DM), four were treated with metformin, one with insulin and two had only dietary treatment. Other significant coexisting conditions are depicted in Table 2.

The subjects underwent four weeks dietary treatment with VLCD Slanka ${ }^{\oplus}$, Table 3, (Slanka Sverige AB, Sweden) corresponding to approximately $680 \mathrm{kcal}$ per day (four portions). Slanka contains milk proteins and approximately $25 \mathrm{~g}$ lactose per $100 \mathrm{~g}$ formula. The main sweetener is sugar beet fructose and secondary Acesulfame $\mathrm{K}$, an artificial sweetener that is excreted unchanged in urine. Slanka contains rapeseed oil fat (information from Slanka Sverige AB, Sweden).

Blood samples were analyzed for $\mathrm{HbA}_{1 \mathrm{c}}$, fasting plasma glucose (FPG), cholesterol and triglycerides. Measurements were done at inclusion and after four weeks of diet. Change in blood pressure and weight was noted. Blood samples were also analyzed for electrolytes, blood cells, CRP and liver enzymes, see Table 3.

Statistical analysis was performed with Stata version 13.1. Skewness/Kurtosis test was used for assessment

Table 1 Baseline demographics

\begin{tabular}{lccc}
\hline & Mean & Standard error & Range (min-max) \\
\hline Age (years) & 48.8 & 1.66 & $33-65$ \\
BMl $\left(\mathrm{kg} / \mathrm{m}^{2}\right)$ & 39.8 & 0.9 & $35.1-49$ \\
Weight $(\mathrm{kg})$ & 107.4 & 3.7 & $85.8-148$ \\
Excess weight $(\mathrm{kg})$ & 40.2 & 2.8 & $24.8-68.6$ \\
\hline
\end{tabular}

Baseline demographics at inclusion. Excess weight is weight exceeding BMI 25.
Table 2 Coexisting conditions in enrolled 25 subjects

\begin{tabular}{lc}
\hline Condition under treatment & Number of subjects \\
\hline Type 2 diabetes mellitus (total) & 7 \\
- Dietary treatment & 2 \\
- Metformin & 4 \\
- Metformin + insulin & 1 \\
Hypertension (total) & 8 \\
- Diuretic & 7 \\
- ACE-inhibitor & 4 \\
- Beta receptor antagonist & 3 \\
Hyperlipidemia (total) & 4 \\
- Statin & 4 \\
Mood disorder (total) & 7 \\
- SSRI & 7 \\
\hline
\end{tabular}

of distribution of data (parametric or non-parametric). Students t-test and Wilcoxon signed-rank test were used for parametric and non-parametric analysis of differences, respectively. P-value $<0.05$ was considered statistically significant.

Table 3 Slanka contents per portion and daily intake

\begin{tabular}{|c|c|c|}
\hline & Per portion $45 \mathrm{~g}$ & Daily intake $180 \mathrm{~g}$ \\
\hline Energy $\mathrm{kcal} / \mathrm{kJ}$ & $170 / 700$ & $680 / 2800$ \\
\hline Proteins $\mathrm{g}$ & 17 & 68 \\
\hline $\begin{array}{l}\text { Carbohydrate } \mathrm{g} \\
\text { (including Fructose g) }\end{array}$ & $17(3,5-5)$ & $68(14-20)$ \\
\hline Fat g & 4 & 16 \\
\hline Fibers $\mathrm{g}$ & 1 & 4 \\
\hline Vitamin A mg & 0.4 & 1.6 \\
\hline Vitamin D $\mu \mathrm{g}$ & 1.8 & 7.2 \\
\hline Vitamin E mg & 3.6 & 14.4 \\
\hline Vitamin K $\mu \mathrm{g}$ & 23 & 92 \\
\hline Tiamine mg & 0.6 & 2.4 \\
\hline Riboflavine mg & 0.9 & 3.6 \\
\hline Niacine mg & 6,2 & 24.8 \\
\hline Vitamin B6 $\mu \mathrm{g}$ & 0.8 & 3.2 \\
\hline Vitamin B12 $\mu \mathrm{g}$ & 1,5 & 6.0 \\
\hline Folacine $\mu \mathrm{g}$ & 76 & 304 \\
\hline Vitamin C mg & 23 & 92 \\
\hline Sodium g & 0.4 & 1.6 \\
\hline Potassium g & 0.7 & 2.8 \\
\hline Calcium g & 0.4 & 1.6 \\
\hline Chloride g & 0.6 & 2.4 \\
\hline Phosphor mg & 400 & 1600 \\
\hline Magnesium mg & 140 & 560 \\
\hline Iron mg & 5.5 & 22.0 \\
\hline Zink mg & 4.8 & 19.2 \\
\hline
\end{tabular}




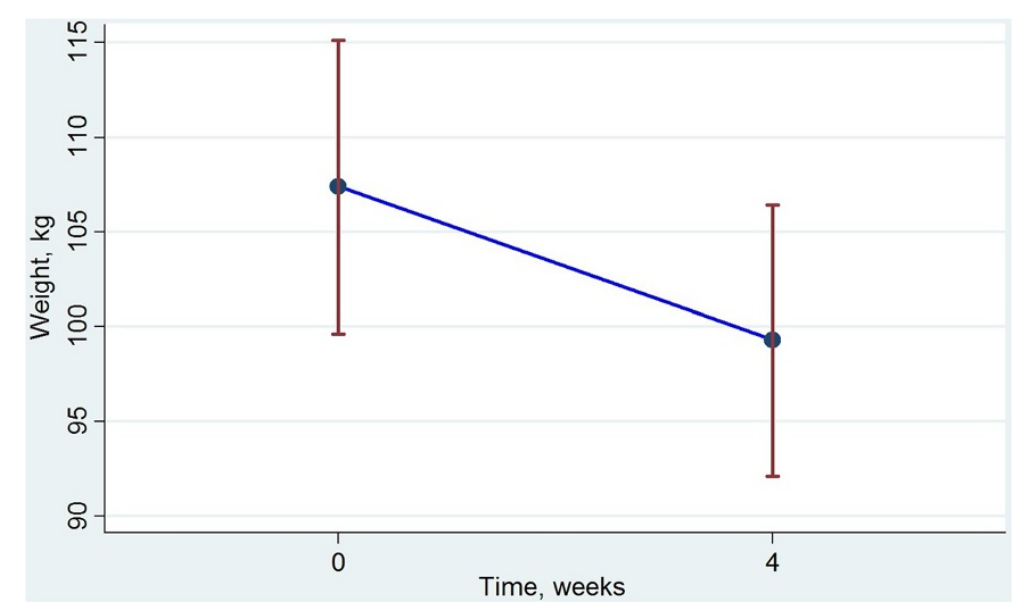

Figure 1 Change in body weight with VLCD. Mean weight ( $95 \%$ confidence interval), $\mathrm{kg}$, before and after 4 weeks dietary treatment with fructose containing VLCD.

\section{Results}

After four weeks of fructose containing VLCD all 25 subjects had mean weight loss of $8.2 \mathrm{~kg}$ as presented in Figure 1. Median excess weight (exceeding BMI 25) loss was 19.5\% (inter quartile range 16.8-24.2). Changes in weight, blood pressure, lipids and FPG are presented in Table 4. All variables except diastolic blood pressure (DBP) were significantly reduced. DBP was significantly increased. It

Table 4 Changes in metabolic variables; weight, blood pressure, glucose and lipids

\begin{tabular}{|c|c|c|c|c|}
\hline \multicolumn{5}{|l|}{ All subjects } \\
\hline Variable & Inclusion & $\begin{array}{l}\text { After diet, } \\
\text { four weeks }\end{array}$ & $P$ & $N$ \\
\hline Weight $(\mathrm{kg})^{*}$ & $107.4(99.6-115.1)$ & $99.3(92.1-106.4)$ & 0.001 & 25 \\
\hline BMI $\left(\mathrm{kg} / \mathrm{m}^{2}\right)^{*}$ & $39.8(38.0-41.6)$ & $36.8(35.1-38.6)$ & 0.001 & 25 \\
\hline Excess weight* & $40.2(34.5-45.9)$ & $32.1(26.8-37.4)$ & 0.001 & 25 \\
\hline $\mathrm{SBP}(\mathrm{mmHg})^{\S}$ & $150(140-150)$ & $135(125-140)$ & 0.005 & 25 \\
\hline $\mathrm{DBP}(\mathrm{mmHg})^{\S}$ & $85(80-90)$ & $90(85-95)$ & 0.04 & 25 \\
\hline Glucose $(\mathrm{mmol} /)^{\S}$ & $5.6(5.3-6.8)$ & $4.8(4.6-5.2)$ & 0.001 & 24 \\
\hline $\mathrm{HbA}_{1 c}(\mathrm{mmol} / \mathrm{mol})^{\S}$ & $39(37-44)$ & $37(35-43)$ & 0.001 & 23 \\
\hline Cholesterol $(\mathrm{mmol} / \mathrm{l})^{\S}$ & $5.4(4.9-6.2)$ & $4.4(4.1-4.9)$ & 0.001 & 22 \\
\hline Triglycerides $(\mathrm{mmol} /)^{\S}$ & $1.6(1.1-2.2)$ & $1.2(1.1-1.6)$ & 0.006 & 21 \\
\hline \multicolumn{5}{|c|}{ Subjects with type 2 diabetes mellitus } \\
\hline Variable & Inclusion & $\begin{array}{l}\text { After diet, } \\
\text { four weeks }\end{array}$ & $P$ & $N$ \\
\hline Weight $(\mathrm{kg})^{*}$ & $119.2(99.3-139.1)$ & $110.3(91.5-129.1)$ & 0.02 & 7 \\
\hline Glucose $(\mathrm{mmol} /)^{\S}$ & $7.5(7.0-12.5)$ & $6.0(4.8-6.8$ & 0.02 & 7 \\
\hline $\mathrm{HbA}_{1 \mathrm{c}}(\mathrm{mmol} / \mathrm{mol})^{\S}$ & $47(44-66)$ & $46(45-59)$ & 0.11 & 7 \\
\hline
\end{tabular}

$\mathrm{SBP}=$ Systolic blood pressure. $\mathrm{DBP}=$ Diastolic blood pressure. *Presented as mean (95\% confidence interval). ${ }^{5}$ Presented as median (inter quartile range). P-value denotes the level of statistical significance in the difference between value at inclusion and after diet. is noteworthy that at inclusion 15 subjects had elevated SBP (above $140 \mathrm{~mm} \mathrm{Hg}$ ). After diet 10 of these were improved but 5 subjects still had elevated SBP.

Five of the seven subjects with T2DM had FPG above $7.0 \mathrm{mmol} / \mathrm{l}$ at inclusion. One subject without known T2DM also presented with FPG above $7.0 \mathrm{mmol} / \mathrm{l}$. Three subjects with T2DM presented with $\mathrm{HbA}_{1 \mathrm{c}}$ levels above 52 $\mathrm{mmol} / \mathrm{mol}$ at inclusion, indicating insufficient treatment T2DM control. One of these improved during treatment with VLCD, and reached normal level of $\mathrm{HbA}_{1 \mathrm{c}}$. The only subject who persisted with FPG above $7.0 \mathrm{mmol} / \mathrm{l}$ after four weeks of diet was the patient with the highest FPG at inclusion, who also had a persisting elevated $\mathrm{HbA}_{1 \mathrm{c}}$ value. Change in FPG and $\mathrm{HbA}_{1 \mathrm{c}}$ levels are presented in Figure 2 and Figure 3, respectively. Change in weight, FPG and $\mathrm{HbA}_{1 \mathrm{c}}$ levels for the diabetic subjects are also presented separately in Table 4.

Triglyceride levels above $1.7 \mathrm{mmol} / \mathrm{l}$ were present in 11 subjects at inclusion, and improved in 6 of these after treatment. Similar results were found regarding cholesterol. Seventeen subjects had cholesterol above $5.0 \mathrm{mmol} / \mathrm{l}$ at inclusion and 12 improved after dietary treatment.

Blood chemistry of electrolytes and blood cell count are displayed in Table 5 . There were only minor or no changes indicating no clinically significant adverse effects of the diet. Liver enzymes AST and ALT were significantly increased, but still well within normal range and the changes were minor.

\section{Discussion}

Four weeks of the fructose containing VLCD Slanka led to improved metabolic control. Overweight was reduced with almost $20 \%$. $\mathrm{FPG}, \mathrm{HbA}_{1 \mathrm{c}}$, triglycerides and cholesterol levels were significantly reduced. Blood pressure was improved. 


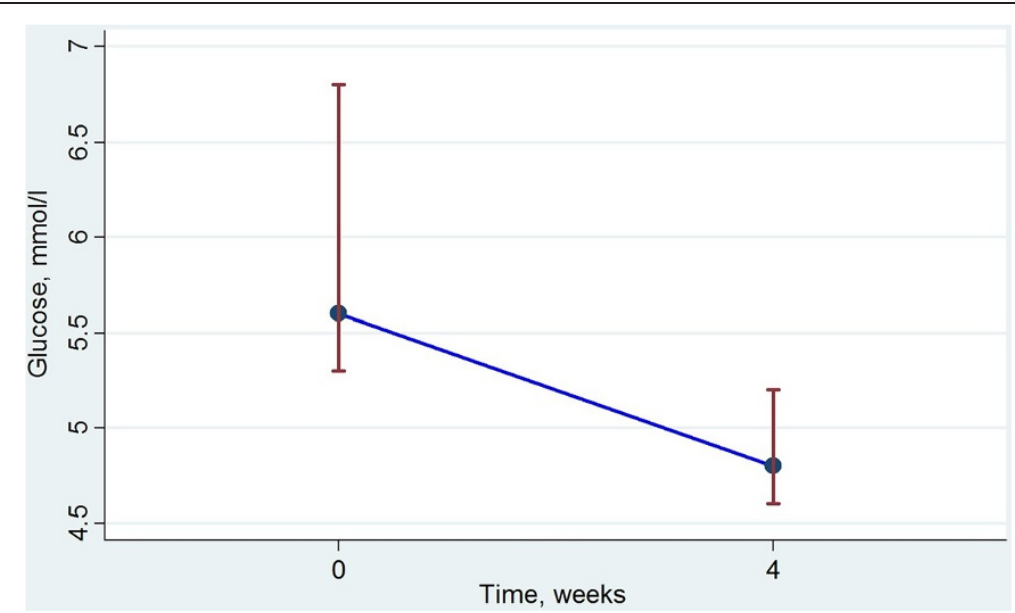

Figure $\mathbf{2}$ Change in fasting glucose with VLCD. Median fasting plasma glucose level (inter quartile range), mmol/l, before and after 4 weeks dietary treatment with fructose containing VLCD.

Liver enzymes were slightly elevated. There is evidence that isocaloric exchange of fructose for other carbohydrates does not induce non-alcoholic fatty liver disease in otherwise healthy individuals. Diets containing high doses of fructose (more than $100 \mathrm{~g}$ per day) may induce changes associated with non-alcoholic fatty liver disease [11]. The small changes in liver enzymes, well within normal range, in the context of a small dose of fructose ( 20 g per day) leads to the conclusion that this change is not a cause for concern during a 4 week treatment.

Although our results clearly indicate improved metabolic control we can draw no certain conclusion as to how the fructose component affected the metabolism. Our study lack a control group and we therefore have to compare with previously published results, summarized in Table 6.

An earlier Swedish trial [12] by Wikstrand et al. investigating an adjunctive 9 months abdominal corset (ie an circumferential abdominal restrain device) treatment versus control after 3 months of VLCD in obese subjects has shown similar results of the dietary treatment as we find in our study. The VLCD (Nutrilett, Cederroth International $\mathrm{AB}$ ) contains fructose, Acesulfame $\mathrm{K}$ and aspartame. The subjects in this study were of same population and age as ours, but had somewhat less overweight. It is interesting to note that the metabolic improvement partially persists 9 months after the diet was finished and is similar to that which we saw immediately after 4 weeks of diet in our study.

Case et al. [13] reports a similar reduction of FGP in an observational consecutive VLCD program in the US including 125 subjects with metabolic syndrome. The VLCD (Nutrimed-Plus, Robard Corporation, Mount Laurel, NJ, USA) used in the study contains approximately 600-800 kcal per day and 30-40 g carbohydrate per

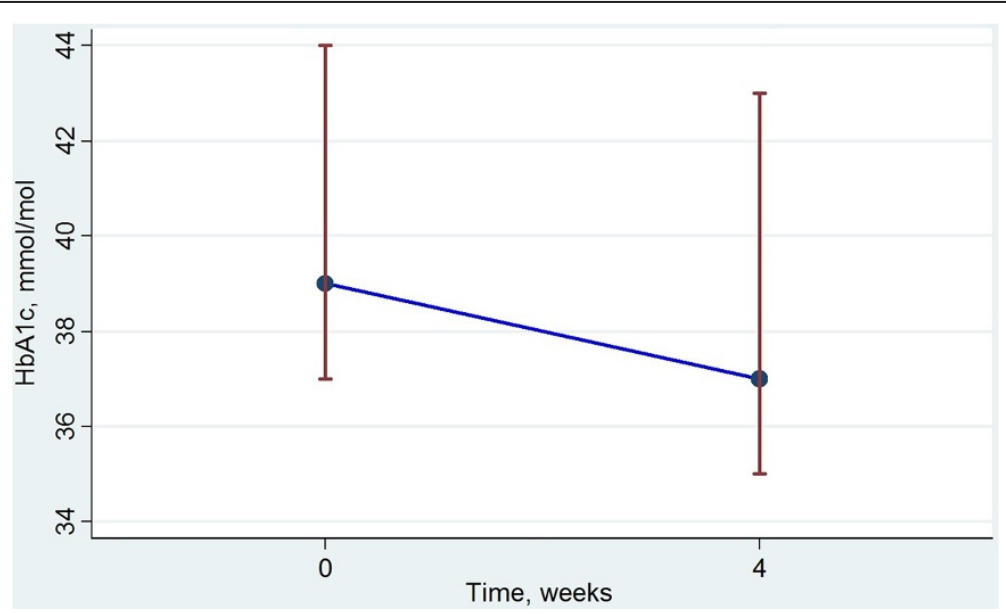

Figure 3 Change in $\mathrm{HbA1c}$ with VLCD. Median $\mathrm{HbA}_{1 \mathrm{c}}$ level (inter quartile range), mmol/mol, before and after 4 weeks dietary treatment with fructose containing VLCD. 
Table 5 Laboratory variables

\begin{tabular}{lcccc}
\hline Variable & Inclusion & $\begin{array}{c}\text { After diet, } \\
\text { four weeks }\end{array}$ & $P$ & $\boldsymbol{N}$ \\
\hline CRP $(\mathrm{mg} / \mathrm{l})^{*}$ & $5.0(4.9-8.0)$ & $<5$ & 0.04 & 25 \\
Hemoglobin $(\mathrm{g} / \mathrm{l})$ & $135(132-140)$ & $138(132.5-143.5)$ & 0.01 & 24 \\
Trombocytes $\left(10^{9} / \mathrm{l}\right)$ & $325(244-389)$ & $316(203-357)$ & 0.01 & 24 \\
White blood cells $\left(10^{9} / \mathrm{l}\right)$ & $6.5(5.9-7.8)$ & $6.8(5.95-7.6)$ & 0.71 & 24 \\
Mean cellular volume (fl) & $88(86-91)$ & $88(85.5-90.5)$ & 0.12 & 24 \\
Sodium (mmol/l) & $140(139-141)$ & $139(139-141)$ & 0.91 & 25 \\
Potassium (mmol/l) & $4.3(4.1-4.5)$ & $4.3(4.1-4.4)$ & 0.04 & 21 \\
Calcium (mmol/l) & $2.37(2.32-2.41)$ & $2.42(2.36-2.47)$ & 0.06 & 25 \\
Creatinine $(\mu \mathrm{mol} / \mathrm{l})$ & $61(53-67)$ & $76(53-75)$ & 0.19 & 23 \\
Bilirubin $(\mu \mathrm{mol} / \mathrm{l})$ & $8(7-10)$ & $9(8-12)$ & 0.03 & 25 \\
ALT $(\mu \mathrm{kat} / \mathrm{l})$ & $0.48(0.37-0.64)$ & $0.53(0.39-0.98)$ & 0.01 & 25 \\
AST $(\mu \mathrm{kat} / \mathrm{l})$ & $0.35(0.30-0.44)$ & $0.42(0.34-0.62)$ & 0.001 & 24 \\
ALP $(\mu \mathrm{kat} / \mathrm{l})$ & $1.36(1.11-1.48)$ & $1.26(0.91-1.39)$ & 0.02 & 25 \\
\hline
\end{tabular}

Changes in non-metabolic blood chemistry values. Presented as median (inter quartile range). P-value denotes the level of statistical significance in the difference between value at inclusion and after diet. *Low-sensitive CRP.

day. VLCD in our study contains approximately $70 \mathrm{~g}$ carbohydrate per day.

Gu et al. performed an observational study [14] in a Chinese population including 53 overweight or obese $(\mathrm{BMI}>28)$ but otherwise healthy subjects. The subjects consumed VLCD with less than $800 \mathrm{kcal}$ per day and less than $20 \mathrm{~g}$ carbohydrate per day for 8 weeks. As seen in Table 6 our diet with a higher amount of carbohydrate led to a more favorable change in FGP level despite shorter treatment and presence of significant comorbidities. The difference between studies can partially be explained by the absence of T2DM - and thus normal FGPD at inclusion - in the Chinese group.
Jackness et al. [15] compared two groups of obese subjects with T2DM in the US. One group underwent bariatric surgery with Roux-en-Y gastric bypass (RYGBP) and the other had VLCD for three weeks. Both groups had high levels of $\mathrm{HbA}_{1 \mathrm{c}}$ at inclusion (mean 66 and $69 \mathrm{mmol} / \mathrm{mol}$ respectively). Insulin sensitivity, $\beta$-cell function and glucose tolerance were measured. The authors conclude that the early beneficial effects after RYGP probably are caused by caloric restriction. Results are strengthened by the Netherlands study of Lips et al. [16]. Our study group contains mainly subjects without T2DM. HbA1c at inclusion was median 39 $\mathrm{mmol} / \mathrm{mol}$. Therefore, as expected, the reduction in FPG is not as explicit in our results.

It has been shown that obese subjects with T2DM started on VLCD, in whom all glucose lowering medication has been discontinued, some subjects respond with reduction of FPG almost immediately, while others did not respond at all. This change in FPG is probably dependent on the capacity of $\beta$-cells to secrete insulin, and is independent of weight change [17]. The same research group has also shown that the positive metabolic effects of 30 day VLCD leads to a sustained improvement in metabolic control up to 18 months follow-up [18].

Although VLCD and other calorie restricted diets have been widely used for many years, there is still scarce of large randomized clinical trials. The effectiveness of a diet is often improved by combination with physical exercise and behavioral interventions [19]. In summary, there is little evidence available to support the extended use of VLCD for weight reduction in obese adults. Little is known of long-term health outcome and quality of life [20]. This is in contrast to the long-term effects of bariatric surgery, which has been studied in detail with known positive effects [3].

Table 6 Literature review of demographics and FPG

\begin{tabular}{|c|c|c|c|c|c|c|c|}
\hline Study & $N\left(Q / \sigma^{7}\right)$ & Age & $B M I$ & FPG at inclusion & FPG after diet & Country & Comments \\
\hline Present study & $25(23 / 2)$ & $48.8(1,66)^{\ddagger}$ & $39.8(0.9)^{\ddagger}$ & $5.6(5.3-6.8)^{\#}$ & $4.8(4.6-5.2)^{\#}$ & Sweden 2013 & 7 subjects with T2DM. 4 weeks diet. \\
\hline Case & $125(? / ?)$ & $48.4(10.4)^{*}$ & $40.7(9.7)^{*}$ & $6.4(2.1)^{*}$ & $5.4(1.2)^{*}$ & U.S. 2002 & Metabolic syndrome. 4 weeks diet. \\
\hline $\begin{array}{l}\text { Wikstrand [12] } \\
\text { - Group A }\end{array}$ & $46(? / ?)$ & $46(9)^{*}$ & $35.4(3,4)^{*}$ & $5.2(0.9)^{*}$ & $4.8(0.5)^{*}$ & Sweden 2010 & $\begin{array}{l}\text { Prevalence of T2DM unknown. } \\
12 \text { weeks diet. }\end{array}$ \\
\hline $\begin{array}{l}\text { Wikstrand [12] } \\
\text { - Group B }\end{array}$ & $48(? / ?)$ & $48(9)^{*}$ & $36.1(3.7)^{*}$ & $5.3(2.2)^{*}$ & $4.7(0.6)^{*}$ & & \\
\hline Yunjuan [14] & $53(? / ?)$ & $?$ & $32.6(0.6)^{\ddagger}$ & $5.3(0.1)^{\ddagger}$ & $5.2(0.1)^{\ddagger}$ & China 2013 & Healthy, no T2DM. 8 weeks diet. \\
\hline $\begin{array}{l}\text { Jackness [15] } \\
\text { - RYGP }\end{array}$ & $11(7 / 4)$ & $44.6(3.0)^{\ddagger}$ & $43.2(2.3)^{\ddagger}$ & $9.9(1.2)^{\ddagger}$ & $6.9(1.2)^{\ddagger}$ & U.S. 2013 & All T2DM. 3 weeks diet. \\
\hline $\begin{array}{l}\text { Jackness [15] } \\
\text { - VLCD }\end{array}$ & $14(8 / 6)$ & $51.9(2.0)^{\ddagger}$ & $39.2(1.0)^{\ddagger}$ & $10.2(0.7)^{\ddagger}$ & $6.1(0.3)^{\ddagger}$ & & \\
\hline
\end{tabular}

Literature review demographics and FPG in different studies. Search was performed using www.pubmed.gov with "VLCD" in combination with either "glucose" "aspartame" or "fructose" as search text. The review was arbitrarily limited to articles published the last 20 years, between 1993 and 2013 and only to include full-text publications. Abstracts were reviewed in order to find results related to the aim of this study; primary outcome FPG levels after VLCD. Fasting serum glucose was treated equal to fasting plasma glucose [11]. All studies except Jackness et al. are observational regarding VLCD. Both groups in Wikstrand et al. received similar VLCD-regime. *Presented as mean (standard deviation). ${ }^{\ddagger}$ Presented as mean (standard error). " Presented as median (inter quartile range). 
We do not find any indicator of metabolic adverse effects resulting from the replacement of aspartame with fructose. Our results with fructose containing VLCD seem to be equivalent to earlier published results from VLCD with artificial sweetener in short-term outcome. The addition of fructose seems to be of lesser importance than severity of hyperglycemia at start of diet. Although there is no strong evidence against use of artificial sweeteners as food additives there are still subjects whom out of personal believe wish to avoid consuming artificial additives. In obese patients preparing for bariatric surgery with VLCD there seems to be no negative metabolic effects regarding blood samples and laboratory analysis measured in this study. Based on this limited observational study we do not find any contraindications for VLCD with fructose instead of artificial sweetener before bariatric surgery.

\section{Abbreviations}

BMI: Body mass index; VLCD: Very low calorie diet; T2DM: Type 2 diabetes mellitus; FPG: Fasting plasma glucose; DBP: Diastolic blood pressure; SBP: Systolic blood pressure; RYGBP: Roux-en-Y gastric bypass.

\section{Competing interests}

$\mathrm{EN}$ and $\mathrm{HF}$ received grant from Slanka Sverige $A B$ in the form of the actual diet for the study as well as financial support for the article processing charge for online publishing. Slanka Sverige AB did not have any part in the initiation or design of the study. EN and HF received grant from Mina Medical $A B$ for a research project regarding a novel endoscopic device for treatment of obesity.

\section{Authors' contributions}

EN participated in the design of the study, performed the statistical analysis, and drafted the manuscript. HF conceived of the study, and participated in its design and coordination and helped to perform the statistical analysis and draft the manuscript. Both authors had read and approved the final manuscript.

\section{Author details}

'Department of General Surgery, Blekinge County Hospital, Lasarettsvägen, 37185 Karlskrona, Sweden. ${ }^{2}$ Blekinge Centre of Competence,

Vårdskolevägen, 37181 Karlskrona, Sweden.

Received: 18 February 2014 Accepted: 16 July 2014

Published: 28 July 2014

\section{References}

1. Flegal K, Carroll MD, Kit BK, Ogden CL: Prevalence of obesity and trends in the distribution of body mass index among US adults, 1999-2010. JAMA 2012, 307:491-497.

2. Freedman DM, Ron E, Ballard-Barbash R, Doody MM, Linet MS: Body mass index and all-cause mortality in a nationwide US cohort. Int $J$ Obes (Lond) 2006, 30:822-829.

3. Sjöström L, Narbo K, Sjöström CD, Karason K, Larsson B, Wedel H, Lystig T, Sullivan M, Bouchard C, Carlsson B, Bengtsson C, Dahlgren S, Gummesson A, Jacobson P, Karlsson J, Lindroos AK, Lönroth H, Näslund I, Olbers T, Stenlöf $\mathrm{K}$, Torgerson J, Agren G, Carlsson LM: Effects of bariatric surgery on mortality in Swedish obese subjects. N Engl J Med 2007, 357:741-752.

4. Marsk R, Näslund E, Freedman J, Tynelius P, Rasmussen F: Bariatric surgery reduces mortality in Swedish men. Br J Surg 2010, 97:877-883.

5. Colles SL, Dixon JB, Marks P, Strauss BJ, O'Brien PE: Preoperative weight loss with a very-low-energy diet: quantitation of changes in liver and abdominal fat by serial imaging. Am J Clin Nutr 2006, 84:304-311.

6. Van Nieuwenhove Y, Dambrauskas Z, Campillo-Soto A, van Dielen F, Wiezer R, Janssen I, Kramer M, Thorell A: Preoperative very low-calorie diet and operative outcome after laparoscopic gastric bypass: a randomized multicenter study. Arch Surg 2011, 146:1300-1305.

7. Butchko HH, Stargel WW, Comer CP, Mayhew DA, Benninger C, Blackburn GL, de Sonneville LM, Getha RS, Herelendy Z, Koestner A, Leon AS, Liepa GU, McMartin KE, Mendenhall CL, Munro IC, Novotny EJ, Renwick AG, Schiffman SS, Schomer DL, Schaywitz BA, Spiers PA, Tephly TR, Thomas JA, Trefz FK: Aspartame: review of safety. Regul Toxicol Pharmacol 2002, 35:1-93.

8. Curtius HC, Endres W, Blau N: Effect of high-protein meal plus aspartame ingestion on plasma phenylalanin concentrations in obligate heterozygotes for phenylketonuria. Metabolism 1994, 43:413-416.

9. SW R: Health implications of fructose consumption: A review of recent data. Nutr Metab (Lond) 2010, 7:82.

10. Ahn Y, Park SJ, Kwack HK, Kim MK, Ko KP, Kim SS: Rice-eating pattern and the risk of metabolic syndrome especially waist circumference in Korean Genome and Epidemiology Study (KoGES). BMC Public Health 2013, 13:61.

11. Chiu S, Sievenpiper JL, de Souza RJ, Cozma A, Mirrahimi A, Carleton AJ, Ha V, Di Buono M, Jenkins AL, Leiter LA, Wolever TM, Don-Wauchope AC, Beyene J, Kendall CW, Jenkins DJ: Effect of fructose on markers of non-alcoholic fatty liver disease (NAFLD): a systematic review and meta-analysis of controlled feeding trials. Eur J Clin Nutr 2014, 68:416-423.

12. Wikstrand I, Torgerson J, Boström KB: Very low calorie diet (VLCD) followed by a randomized trial of corset treatment for obesity in primary care. Scand J Prim Health Care 2010, 28:89-94.

13. Case CC, Jones PH, Nelson K, O'Brian Smith E, Ballantyne CM: Impact of weight loss on the metabolic syndrome. Diabetes Obes Metab 2002, 4:407-414.

14. Gu Y, Yu H, Li Y, Ma X, Lu J, Yu W, Xiao Y, Bao Y, Jia W: Beneficial effects of an 8-week, very low carbohydrate diet intervention on obese subjects. Evid Based Complement Alternat Med 2013, 2013:760804.

15. Jackness C, Karmally W, Febres G, Conwell IM, Ahmed L, Bessler M, McMahon DJ, Korner J: Very low-calorie diet mimics the early beneficial effect of Roux-en-Y gastric bypass on insulin sensitivity and $\beta$-cell function in type 2 diabetic patients. Diabetes 2013, 62:3027-3032.

16. Lips MA, de Groot GH, van Klinken JB, Aarts E, Berends FJ, Janssen IM, Van Ramshorst B, Van Wagensveld BA, Swank DJ, Van Dielen F, van Dijk W, Pijl $\mathrm{H}$ : Calorie restriction is a major determinant of the short-term metabolic effects of gastric bypass surgery in obese type 2 diabetic patients. Clin Endocrinol (Oxf) 2013, epub ahead of print.

17. Jazet IM, Pijl H, Frölich M, Schoemaker RC, Meinders AE: Factors predicting the blood glucose lowering effect of a 30-day very low calorie diet in obese Type 2 diabetic patiens. Diabet Med 2005, 22:52-55.

18. Jazet IM, de Craen AJ, van Schie EM, Meinders AE: Sustained beneficial metabolic effects 18 months after a 30-day very low calorie diet in severely obese, insulin-treated patients with type 2 diabetes. Diabete Res Clin Pract 2007, 77:70-76.

19. Shaw KA, O'Rourke P, Del Mar C, Kenardy J: Psychological interventions for overweight or obesity. Cochrane Database Syst Rev 2005, 2:CD003818.

20. Avenell A, Brown TJ, McGee MA, Campbell MK, Grant AM, Broom J, Jung RT, Smith WC: What are the long-term benefits of weight reducing diets in adults? A systematic review of randomized controlled trials. J Hum Nutr Diet 2004, 17:317-335.

doi:10.1186/1475-2891-13-77

Cite this article as: Norén and Forssell: Very low calorie diet without aspartame in obese subjects: improved metabolic control after 4 weeks treatment. Nutrition Journal 2014 13:77. 